\title{
CDP Water Program 2015 Turkey Results
}

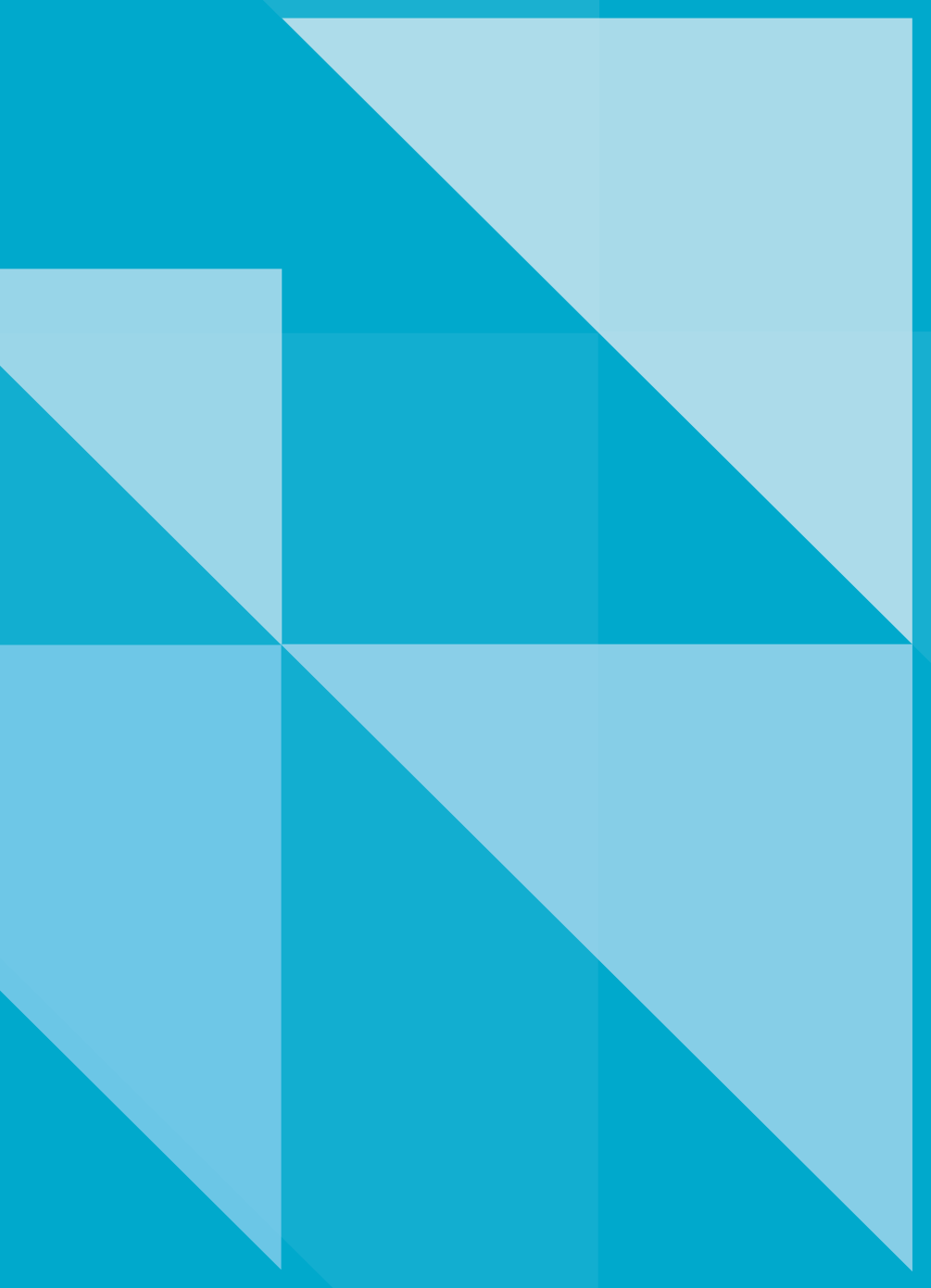




\title{
Sponsor Foreword
}

\author{
"We are honored to have 15 companies responding \\ to CDP Water Program in its first year of \\ implementation in Turkey. We genuinely wish this \\ number to increase each year so that we can \\ prevent the destructive consequences of water \\ scarcity for society and the environment by working \\ all together side-by-side."
}

As Garanti Bank, we are proud to be a part of CDP Water Program, launched by Sabancl University Corporate Governance Forum, that marks a new era for water issues in Turkey. The results of 2015 CDP Global Water Report and results of Turkey hold significant data regarding not only environmental impacts, but also economic and social impacts. CDP Global Report reveals the water status in our country with striking results that if today's consumption habits continue and necessary actions are not taken, water will become a global crisis in the near future, and have detrimental effects on economies and societies. It goes without saying that this upcoming water crisis can only be tackled with the participation of all stakeholder groups in multinational platforms.

We believe that the fundamental principle of responsible and sustainable banking is to think of the consequences of our actions beforehand. The entire business world should go above and beyond and take necessary actions in their entire value chain on top of efficient use of water in their operations. Effective water management should be a part of their business processes, and companies should take the water cycle into consideration when developing business strategies and setting targets. Accordingly, by supporting CDP Water Program, we aim to convey the integrated water management concept over a broader audience in Turkey and encourage our corporate customers to acknowledge the risks regarding water resources.

This year, we expanded the scope of our ISO14001 Environmental Management System, in which protecting water resources is one of the main topics, covering our entire operations in Turkey. Besides our own water management, we also manage our indirect water footprint by assuring that all necessary actions are taken to reduce the consumption of water and other natural resources, to apply waste management \& recycling, and to eliminate all activities resulting in negative impacts on water quality.

We are honored to have 15 companies responding to CDP Water Program in its first year of implementation in Turkey. We genuinely wish this number to increase each year so that we can prevent the destructive consequences of water scarcity for society and the environment by working all together side-by-side.

\section{Ebru Dildar Edin Executive Vice President Garanti Bank}




\section{"I believe that one of that factors that led to this more than satisfactory beginning for the CDP Water Program in Turkey is the awareness of water related risks amongst the participants of the CDP Climate Change Program. Since 2010, water security has been highlighted as one of the most serious and immediate risks associated with climate change in Turkey by the reporting companies."}

I am pleased to report that the positive trend of non-financial disclosure by Turkey's largest companies observed during the past few years is accelerating as evidenced by the number of companies that responded to the invitation to participate in CDP's Turkish Water Program.

In 2015, 15 Turkish companies, reported their water-related risks through CDP's Water Program. The participants included some companies that were identified as high water impact using CDP's screening methodology and hence invited to disclose their water risk management and stewardship policies, as well as companies that participated voluntarily. We are delighted to see that the finance sector has already included water security issues in their risk management processes in Turkey as evidenced by the voluntary disclosure by two banks. I believe that one of that factors that led to this more than satisfactory beginning for the CDP Water Program in Turkey is the awareness of water related risks amongst the participants of the CDP Climate Change Program. Since 2010, water security has been highlighted as one of the most serious and immediate risks associated with climate change in Turkey by the reporting companies.

The World Economic Forum has ranked global water crises - including drought, increased risk of flooding and deteriorating water quality - as the greatest threat facing the planet; CDP's new global water report, 'Accelerating action', shows that some companies are beginning to move ahead of the pack in addressing water concerns.

Scientists and experts agree that Turkey is among the most vulnerable countries that will face severe water shortages by 2025 . The CDP Water Program will help bring the foresight shown by pioneering companies in high impact sectors such as food, cement, textile and automotive, to the attention of the lagging companies, their stakeholders, the regulators and concerned citizens. We hope that CDP Water Program will provide a credible platform for a dialog between companies and their stakeholders about the means and ways of instituting effective water stewardship in business conduct in going forward.

We are indebted to Garanti Bank, the sponsor of CDP Water Program in Turkey, and Deloitte Turkey, our reporting partner for their support.

\section{Melsa Ararat, PhD \\ Director \\ CDP-Turkey}




\section{Executive Summary}

In a year when the World Economic Forum has ranked global water crises - including drought, increased risk of flooding and deteriorating water quality - as the greatest threat facing the planet over the next decade in terms of impact, CDP's new global water report, 'Accelerating action', shows that some companies are beginning to move ahead of the pack in addressing water concerns.

Through its water questionnaire, which outlines a framework for corporate stewardship and its global disclosure system, CDP has built the world's largest database of primary corporate responses to water risk and opportunity. Analysis of this database provides a clear business case for water stewardship. It also highlights how the corporate response to water risk has, thus far, been inadequate and suggests that opportunities for business growth may be overlooked.

There is growing interest among institutional investors in waterrelated risk, opportunity and disclosure. This year 617 institutional investors asked 1,073 of the world's largest publicly listed companies across industry sectors with high water vulnerability or impacts to disclose how they are adapting and responding to worsening water security. CDP's new global water report analyzes the 405 (including companies from Turkey) company responses to this request - over twice the number of companies analyzed in 2014.

In 2015, Sabancı University Corporate Governance Forum launched CDP Water Program Program in Turkey with the support of Garanti Bank. CDP Turkey invited the 51 largest companies listed to disclose information regarding water resources. In total 15 companies responded to CDP Water program from Turkey. This report includes the analyses of CDP Turkey responses.

The report is intended to help companies in Turkey that are sensitive to, or have major impacts on, water availability or quality, to show how are they managing risks, and positioning themselves to participate in the water value revolution.

\section{Key Findings}

Disclosure levels are quite low in CDP Turkey's official sample. $84 \%$ of 51 Turkish companies failed to disclose in 2015. On the other hand, seven companies disclosed to CDP voluntarily (Self selected companies SSCs) although they are not invited by CDP. There may be a lot of reasons behind the low disclosure levels such as being invited by CDP Water Program for the fist time, the absence of robust water policies in place, the absence of water related data and the absence of national water strategy to follow, etc.

$36 \%$ of respondents have already seen water risk manifest itself as a detrimental impact to their business in the last reporting year.

Water security remains a fundamental business imperative for many companies in Turkey. $64 \%$ of responding companies report that water poses a substantive risk to their business.
There is no company in Turkey with a robust and comprehensive water policy in place. Such policies should be companywide, set performance standards for direct operations and supply chains, set out clear goals and guidelines for action, recognize the human right to water, sanitation and hygiene.

Physical risk drivers - increased water scarcity or stress, declining water quality, drought etc.- are the most commonly cited. Two thirds $(\mathbf{7 5} \%)$ of 35 different type of water related risks are physical.

$86 \%$ of responding companies report that water offers operational, strategic or market opportunities. The most significant opportunities are related to 'cost saving' and 'improved water efficiency'. Many respondents stated that the costs savings would be achieved through the reduction of the water consumption.

7 There is a room for improvement in water risk assessment. Only $14 \%$ of respondents undertake a comprehensive company wide risk assessment that covers both direct operations and their supply chain. Especially comprehensive supplier engagement policies regarding water in the entire value chain is missing for most of the Turkish companies.

Vorporate water stewardship is becoming a major issue at the board level. $79 \%$ of respondents report that oversight of water policy, strategy and planning rests at the board level.

Valf of the respondents put targets and goals in place. $79 \%$ of responding companies reporting qualitative goals leading towards improved water stewardship; and $50 \%$ of respondents reporting targets with quantitative actions to manage water resources.

Top quantitative targets reported by responding companies are:

- Absolute reduction of water withdrawals

$\checkmark$ Improvement of monitoring water use

$\checkmark$ Reduction of water intensity

Top company wide qualitative goals are:

$\checkmark$ Sustainable agriculture

$\checkmark$ Educate customers to help them minimize product impacts

$\checkmark$ Strengthen links with local community. 
Number of respondents
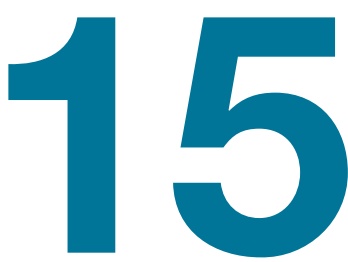

Respondents reporting detrimental impacts related to water

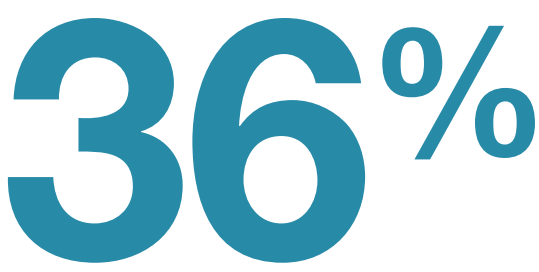

Number of risks reported

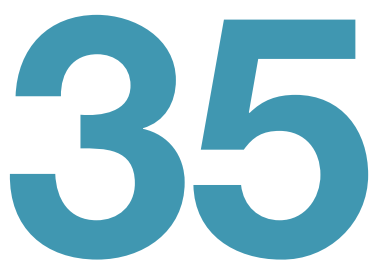

Respondents reporting opportunities

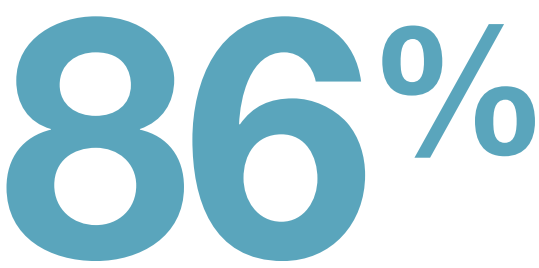

Total amount of water withdrawn by responding companies (megalitres)

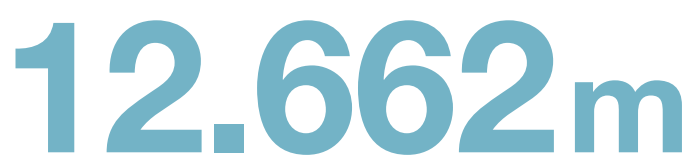

Total amount of water consumed by responding companies (megaliters)

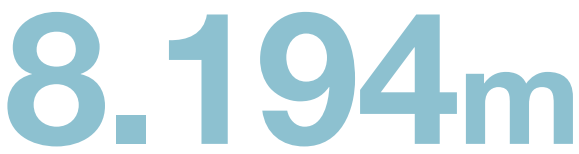

Respondents reporting that water poses a substantive risk to direct operations

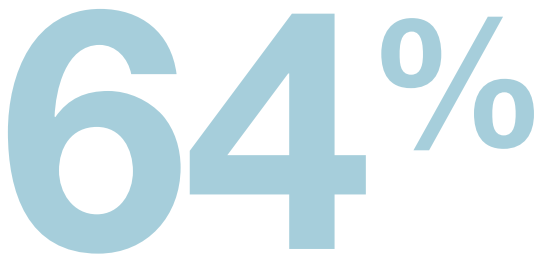

Figure 1: Respondents by sector
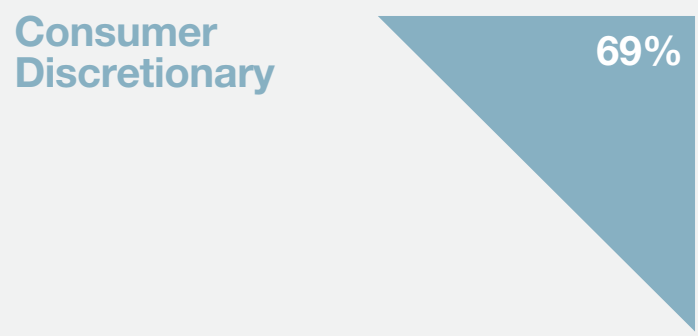

Industrials

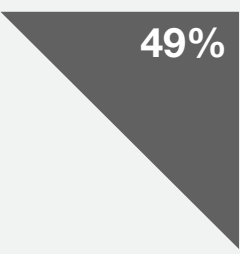

Materials

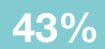

Utilities

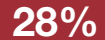

Consumer

Staples

Financials 
Dünya Ekonomi Forumu'nun dünyayı önümüzdeki yıllarda kötü etkileyebilecek kuraklık, artan sel tehlikesi ve bozulan su kalitesi gibi küresel su krizlerine dikkat çektiği bir yılda, CDP'nin 'Accelerating Action-Aksiyonu Hızlandırma' bașlıklı yeni küresel su raporuna göre bazı șirketler öncü bir rol oynayarak su ile ilgili sorunları dile getirmeye bașladı.

CDP șirketlere yönelttiği su ile ilișkili sorulara aldığı yanıtlar sayesinde su riskleri ve fırsatlarına dair dünyanın en kapsamlı kurumsal veritabanını olușturmuștur. Bu veritabanında yer alan bilgilerin analizi sayesinde su yönetimine ilișkin çok kapsamlı çalıșmalar yapılabilmektedir. Maalesef bu veritabanında yer alan verilere göre kurumların șimdiye kadar su riskini yeteri kadar ciddiye almadığı görülüyor ve ișletmetlerin sürdürülebilir bir büyümeye yönelik fırsatları bu nedenle kaçırılabileceği vurgulanıyor.

Kurumsal yatırımcıların șirketlerin maruz kaldığı suyla ilișkili risk ve fırsatların açıklanmasına yönelik talepleri gitgide artıyor. Bu yı 617 kurumsal yatırımcı, üretim sektörlerinde faaliyet gösteren ve su güvenliğinden büyük oranda etkilenen, dünyanın halka açık en büyük șirketlerinin 1.073'ünden su ile ilgili sıkıntılara nasıl uyum sağladıklarını ve kötüleșen su güvenliğine karșı nasıl önlemler aldıklarını açıklamalarını istedi. CDP'nin yeni küresel su raporunda, bu talebe yanıt veren (Türkiye'den șirketler de dahil) 405 șirket analiz ediliyor bu sayı 2014'te analiz edilen șirket sayısının iki katından bile fazla.

Sabancı Üniversitesi Kurumsal Yönetim Forumu, Garanti Bankası'nın ișbirliği ile 2015 yılında Türkiye'de CDP Su Programı'nı bașlattı. Program kapsamında Türkiye'den davet alan 51 șirket, BIST-100 endeksinde yer alan șirketlerin içerisinde suya bağlı risklere en çok maruz kalma olasilı̆̆ı olan sektörlerde yer alan șirketlerden olușuyor. Davet alan șirketlerin yanısıra CDP'den davet almadığı halde gönüllü yanıt verenlerle beraber bu sene toplamda 15 șirket CDP'ye yanıt verdi.

Bu raporda CDP Türkiye'ye sunulan yanıtların analizine yer veriliyor ve Türkiye'de șirketlerin suya bağlı riskleri nası yönettiği ve su değer devriminde kendilerini nasıl konumlandırdığı konusunda kamuoyunu bilgilendirmeyi amaçlıyor.

\section{Ana Çıktılar}

Türkiye'de CDP'nin davet yolladığı șirketlerin yanıt verme oranı çok düșük. Davet yollanan 51 șirketin \%84'ü 2015 yliında CDP Su Programı'na yanıt vermedi. Öte yandan CDP tarafindan davet edilmeyen yedi șirket gönüllü olarak açıklama yaptı. Yanıt verme oranının düșüklüğü CDP Su Programı'na illk defa davet edilmiș olma, șirketin etkin bir su politikasının olmaması, suya ilișkin verilerin eksikliği ve ulusal bir su stratejisinin olmayıș gibi birçok nedenle bağdaștırlabilir.

CDP'ye yanıt veren șirketlerin \%36's son raporlama ylinda sudan kaynaklı olumsuz etkilere maruz kaldığını bildiriyor.

Su güvenliği, Türkiye'deki pek çok șirket için temel bir ticari problem. Raporlama yapan șirketlerin \%64'ü suyun ișletmeleri için önemli bir risk haline geldiğini bildiriyor.
Türkiye'deki hiçbir șirket etkili ve kapsamlı bir su politikası benimsemiș değil. Böyle bir politika için suya yönelik stratejilerin șirketin tüm stratejlerine entegre edilmesi, doğrudan operasyonlar ve tedarik zincirlerine yönelik performans standartlarının belirlenmesi, atılacak adımların net bir șekilde belirlenmesi, su, sağlık ve hijyenin insanların temel hakkı olduğunun kabul edilmesi gerekiyor.

Artan su kıtlığı veya stresi, bozulan su kalitesi, kuraklik gibi fiziksel risk faktörleri yanit veren șirketler tarafindan en çok dile getirilen risk faktörleri. Suya ilișkin raporlanan $\mathbf{3 5}$ farklı riskin dörtte üçünün (\%75) fiziksel riskler olduğu görülüyor.

Yanit veren șirketlerin \%86'sı suyun operasyonel, stratejik veya ekonomik firsatlar sunduğunu bildiriyor. Bu firsatlardan en önemlileri 'maliyet tasarrufu' ve 'artan su verimliliği' ile ilișkili. Açılamada bulunan șirketlerin çoğu su tüketimini azaltarak maliyet tasarrufu sağlanabileceğini düșünüyor.

Su riski değerlendirmesi konusunda da büyük eksikler var. Bu șirketlerin sadece \%14'ü doğrudan operasyonlarını ve tedarik zincirlerini kapsayan genel bir risk değerlendirmesi yapmıș durumda. Türk șirketlerinin çoğu henüz değer zincirinde tedarikçileri su konularına dahil eden kapsamlı politikalar benimsemiș değil.

Yanıt veren șirketlerin \%79'u su politikalarının, stratejilerinin ve planlamasının, yani bütünüyle kurumsal su yönetimi konusunun yönetim kurulu seviyesinde ele alındığını bildiriyor.

Yanıt veren șirketlerin yarısı suya yönelik hedefler belirlemiș durumda. Șirketlerin \%79'u su yönetimini iyileștirmeye yönelik niteliksel hedefler koyarken, \%50'si ise niceliksel hedefler bildiriyor.

Șirketlerin bildirdiği niceliksel hedeflerin bașinda:

\ Çekilen suyun azaltıması

\ Su kullanımı takibinin iyileștirilmesi

\ Su yoğunluğunun azaltılması geliyor.

Niteliksel hedeflerin bașındaysa:

จ Sürdürülebilir tarım

\ Müșterilerin eğitimi

\ Bölge halkılya ilișkileri kuvvetlendirmek geliyor. 
Yanıt veren șirketlerin sayısı
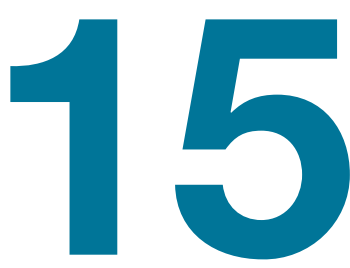

Suya bağlı risklerden olumsuz etkilendiğini bildiren șirketlerin oranı

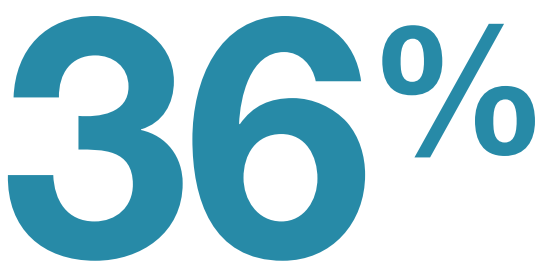

Bildirilen risk sayısı

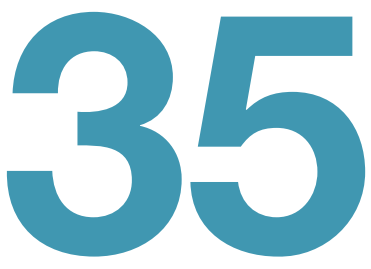

Suyun fırsat yarattığını bildiren șirketlerin oranı

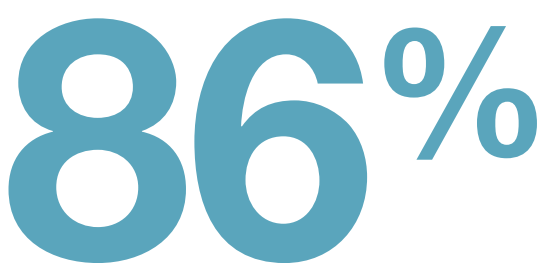

Açıklama sunan șirketlerce çekilen suyun toplam miktarı (megalitre)

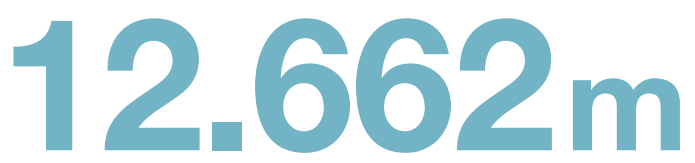

Açıklama sunan șirketlerce tüketilen suyun toplam miktarı (megalitre)

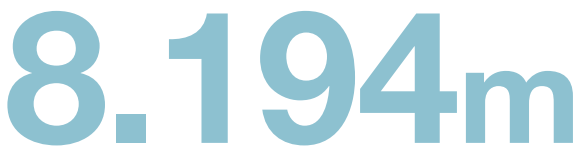

Suyun ișletmelerine karșı önemli bir risk olușturduğunu bildiren șirketlerin oranı
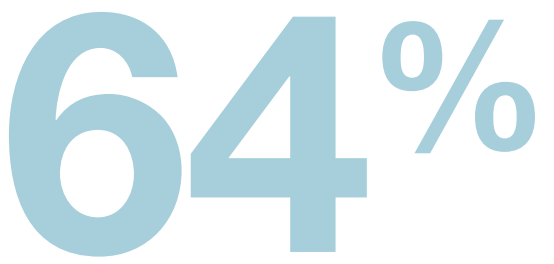

Figür 1: Sektörlere göre yanıt verme oranları

\section{Consumer \\ Discretionary}

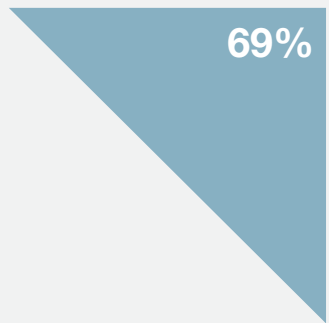

\section{Industrials}

Materials

\section{Utilities}

Consumer

Staples

Financials 


\section{Company Responses Oveview and Key Findings}

\section{CDP's water program aims to catalyse action, to ensure that water security - one of the most pressing challenges facing the global economy - is accorded the strategic importance it deserves.}

In 2015, CDP Turkey invited 51 companies (CDP Turkey Water Program Sample 1 to disclose information regarding water resources. The high impact sub-industry list as a filter has applied to BIST-100 index companies to reduce the list down to 51 companies. Below are the primary sections of the CDP Information request²:

\section{Water resource management and governance at the corporate level \\ Perceived risks and opportunities related with water and strategies adopted to manage them \\ Water withdrawal, consumption and discharge strategies}

\section{Response rates:}

The response rate to CDP's information request is influenced by a range of factors, including companies' profile, resources, degree of the familiarity with the CDP process and the general appreciation of water issues.

This year is the first year of CDP Water reporting in Turkey and 15 companies responded to CDP. Out of 15 companies, 8 are self selected (SSCs) ${ }^{3} 7$ are invited by CDP and 1 is see another (SA) ${ }^{4}$ company. In total 51 companies are invited therefore response rate is $16 \%$. This response rate is likely to improve each year as companies become more aware of the issues of water resources of Turkey, and gain familiarity with the CDP process.

CDP Turkey: Water Program Respondents in 2015

\section{Company (CDP Turkey Water Sample)}

AKENERJi ELEKTRIK ÜRETIM A.Ș.

AKSA AKRILIIK KIMYA SANAYIII A.Ș.

BRISA BRIDGESTONE SABANCI LASTIK SAN. VE TIC. A.Ș

ÇIMSA ÇIMENTO SANAYIi VE TICARET A.Ș.

COCA-COLA IÇECEK A.Ș.

TAV HAVA LIMANLARI HOLDING A.Ș.(Env list)

TESCO KIPA (TesCO)

TOFAȘ TÜRK OTOMOBIL FABRIKASI A.Ș.

\section{Company (Other Responding Companies)}

AKÇANSA ÇIMENTO SANAYI VE TICARET A.Ș.

IHLAS EV ALETLERI IMALAT SANAYI VE TICARET A.Ș.

IHLAS HOLDING A.Ș.

PINAR SÜT MAMULLERI SANAYIi A.Ș.

ȘEKERBANK T.A.Ș.

T.GARANTI BANKASI A.Ș.

YÜNSA YÜNLÜ SANAYI VE TICARET A.Ș.

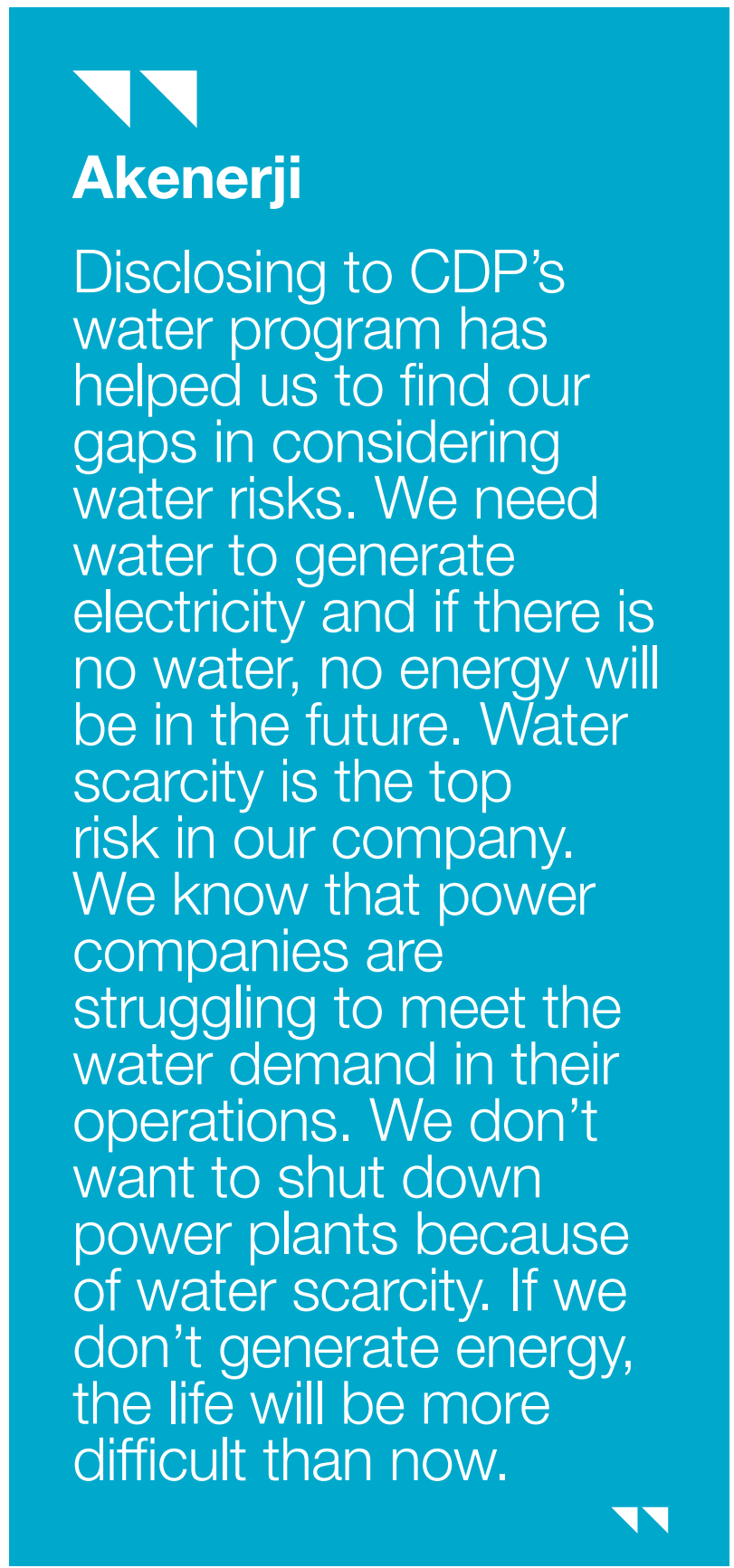

1: A specific population of companies selected by market capitalisation and/ or geography.

2: The letter and questionnaire dispatched by CDP to all companies in CDP samples (including the Turkey Water Sample) on 1st February of every year, requesting information on environmental disclosure.

3: Companies responding to CDP information requests who are not in a CDP Sample.

4: Company is either a subsidiaryor has merged during the reporting process. 


\section{Risk and Opportunities}

\section{The responses to this year's information request underline the business case for action on water security. Companies report widespread risk and material impacts - but they also recognise that water stewardship offers the potential to reduce costs and increase revenues.}

\begin{abstract}
A. Risks
In common with other developing countries, water poses both risks and opportunities for Turkey. These risks may be regulatory, physical and reputational or may be either direct or indirect (e.g. impacting business partners, suppliers and/or customers).
\end{abstract}

\section{a) Regulatory risks:}

Regulatory risks may arise from an expected or unexpected change or uncertainty, in law or regulation that may have direct or indirect impacts on a company. A change in law or regulation can increase the costs of operating a business, reduce the attractiveness of an investment, or change the competitive landscape in which a company operates. Some of the respondents stated that it is highly probable that stricter regulations in water supply and point source pollution regulations may cause higher water prices in the near future. For instance Coca Cola liçecek pointed to the potential regulatory limitations for water discharge amounts supported by Ergene Basin Protection Plan.

The majority of respondents stated that they have already developed, or are in the process of developing strategies and programmes to manage risks associated with the regulation. Such strategies include Legal and Regulatory tracking, including cross-functional efforts to stay informed of new legislation and regulations related to water resources. Another strategy is taking water management incentives such as Rewarding System and Performance Management System. Employees are rewarded on their achievement in water reduction goals and saving projects.

\section{b) Physical risks}

Physical risks may arise from water stress or scarcity (too little water), flooding (too much water) or pollution (lower water quality). Disruption in water supply or decline in water quality can adversely affect operations where water is used for production, irrigation, material processing, cooling, washing and cleaning, and personal consumption. Physical risks can adversely affect production or cause damage to physical assets.

Eight of the responding companies state that physical risks related to water are the most significant risks for their industries, the consequences ranging from flooding, drought to declining water quality.

In order to manage the physical risks, Garanti Bank stated that their Business Continuity Management Plan cover all

Figure 2: Type and number of risks reported

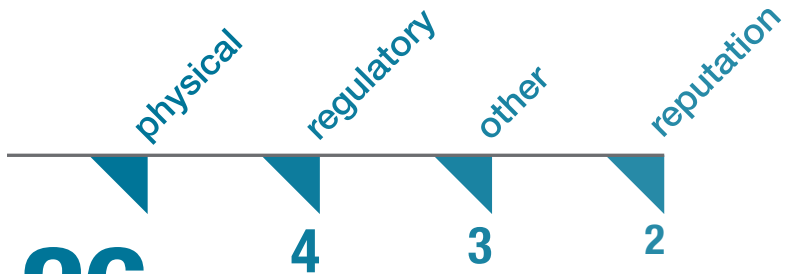

the possible natural disaster or significant hazard to ensure continuity in customer service, fulfill legal obligations, minimize financial losses, provide employee security and safeguard information assets. Akçansa Çimento stated that employees will have performance initiatives related water management and/ or reduction target. Brisa had flooding problems in 1998 after which Brisa had built an 800 meter long flood barrier and also installed flood gates where the excess water is pumped back to the river.

\section{c) Reputational risks}

They may arise from impacts resulting from litigation, product risks due to changes in consumer behavior, and risks that may impact decisions made by investors, consumers and current/ potential employees concerning a company. There are three companies reported reputational risks such as:

Garanti Bank points out the Negative Media Coverage risk

For Coca Cola İçecek, there is a reputational risk due to inadequate access to water, sanitation and hygiene

\section{d) Other risks:}

There are two companies reported earthquake under other risks category. Coca Cola lccecek stated that there is active Sivrice Fault zone very close to the resource and an earthquake may cause loss of resources due to undesired change in the crack system within rocks.

\section{$\sqrt{10}$}

TAV Airports

“Disclosing to CDP's water program

has helped us to put water on our corporate agenda with a much stronger emphasis. CDP provided us with a thorough framework on water, which steered us toward assessing water-related issues in a wider context. We are committed to minimizing the impact of our operations on vulnerable freshwater resources while maintaining the highest quality of service for our passengers. We believe that a concerted action of corporations is vital to help secure the right to water for future generations and CDP's water program will provide a key platform to achieve this goal" 


\section{Risk and Opportunities}

\section{B. Opportunities}

While climate change causes several risks it also presents opportunities for businesses.

Changes in water availability and climatic conditions related to water may provide commercial opportunities to some companies. These opportunities may include; increased operational efficiency, cost-reducing process and/or supply chain re-design, the creation of new markets for water products, improved finance and/or risk management procedures, enhanced reputation and the ability to influence government policy.

As illustrated in Figure 3 below, the most significant opportunities are perceived to be 'cost saving opportunity' and 'improved water efficiency'. Many respondents stated that the costs savings would be achieved through the reduction of the water consumption.

\section{Çimsa Çimento}

Disclosing to CDP's water program

has helped us to realize which

level we are and obtain to see

the missings in order to improve

new strategies related with

water consumption volume and

measurements of details in our

process. Improving water risk and

opportunity assessments in our

operation by integration to program

as one of the leading company

in cement industry, to encourage

other companies by responding

CDP-Water program and enhance

reputation as well as to raise

awareness.
Numerous companies report reduced costs as a result of improved water efficiency.

- AkçanSA has runoff water recycling systems and is planning for rainwater collection systems.

Aksa Akrilik Kimya believes that renovation of deionized water treatment plant will result in cost savings.

In 2014, Coca Cola İçecek saved nearly annual 60000 $\mathrm{m} 3$ water as a result of water reuse/recycle projects implemented at Elazıg, Bursa , Köyceğiz and Sapanca plants.

\section{In terms of new markets and developments}

AKSA is working on reduce the water usage in the production of acrylic fiber process.

Brisa is investing on new technologies like reverse osmosis, treatment plants; water efficiency projects like building up a circular system for cooling water; increasing employee awareness by trainings; investments on waterless urinal systems and water efficient faucets for domestic water usage.

"Agriculture of the Future Project" which has been has been conducted in partnership with the Coca-Cola Life Plus Foundation, the Ministry of Food, Agriculture and Livestock and the Nature Conservation Center, aims to promote the use of ecosystem approach and improve climate change adaptation in agriculture. In order to do this, the project has two main components, direct seeding and windbreaks.

Figure 3: Types of opportunities reported

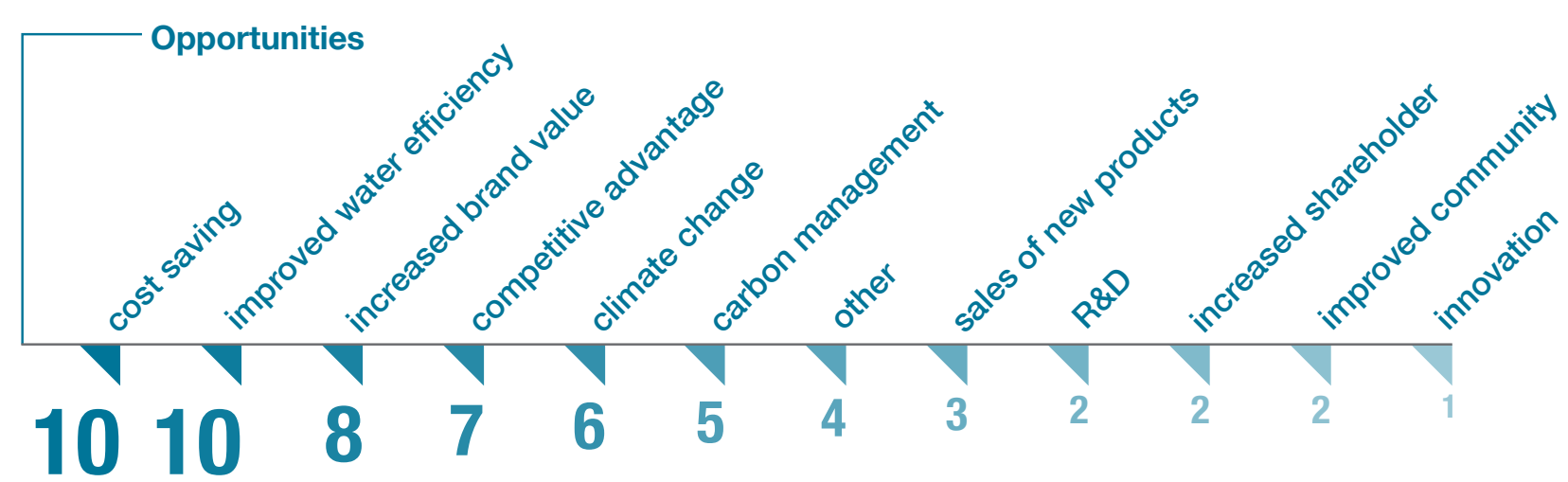




\section{Water Risk Management}

The good news is that respondents are acknowledging the importance of water security as a corporate issue. The responses to CDP's water questionnaire shows a clear progress on some of the most important indicators of effective water risk monitoring and management. A wealth of experience is being accrued that will prove invaluable to those companies taking their first steps towards comprehensive water risk management and improved water stewardship.

\section{Approximately one third (36\%) of respondents} experienced detrimental impacts related to water challenges in the reporting year. All the reported impact indicators are physical. Some of the impacts are Reduction in revenue, plant/production disruption leading to reduced output, higher operating costs and supply chain disruption. Șekerbank states that 4 of the branches located in different river basins had negatively affected from flood in 2014.

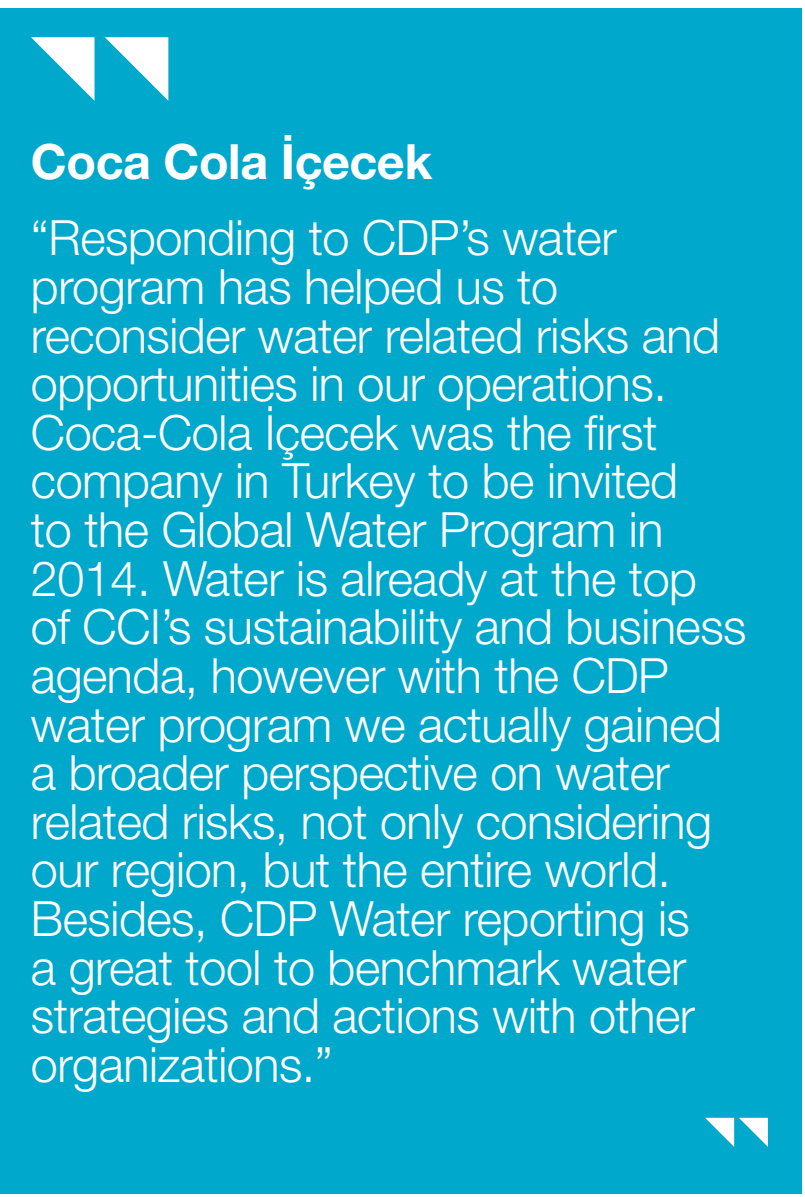

\section{Respondents that have experienced detrimental water-related business impacts in the reporting year}

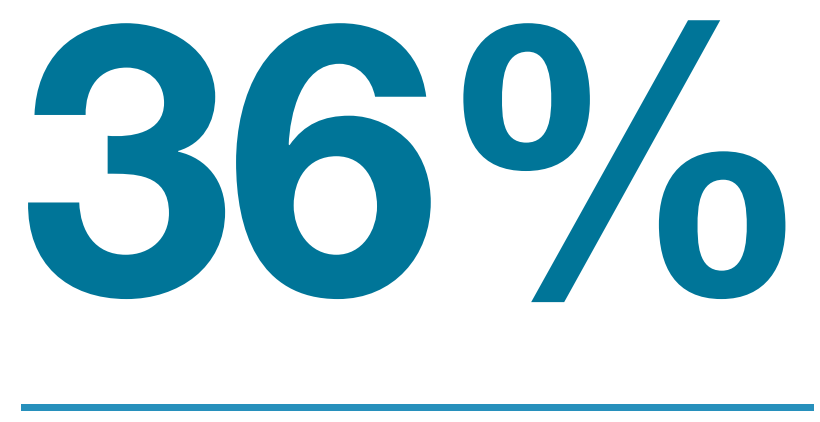

Respondents reporting that water poses a substantive risk to their business
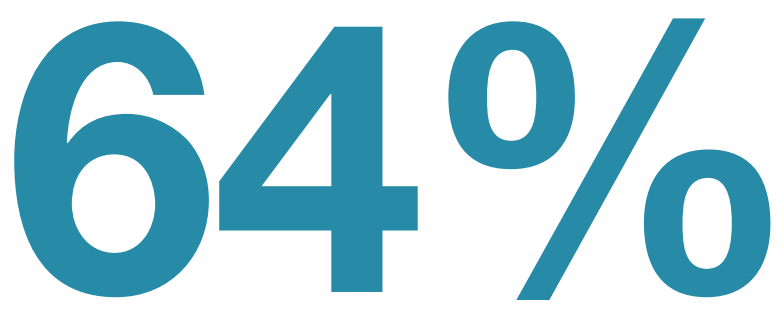

Respondents that undertake a comprehensive company wide risk assessment that covers both direct operations and supply chain
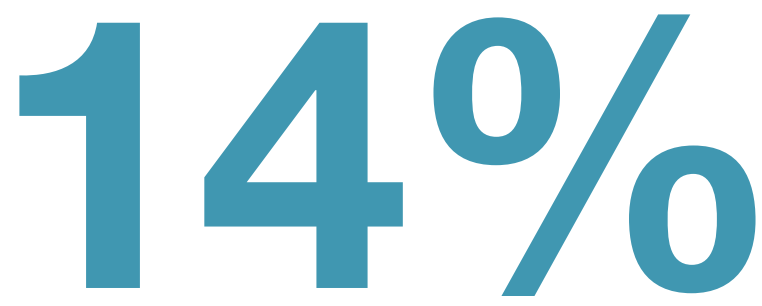

Respondents consider the impact of increasing regulation around water in their risk assessment processes
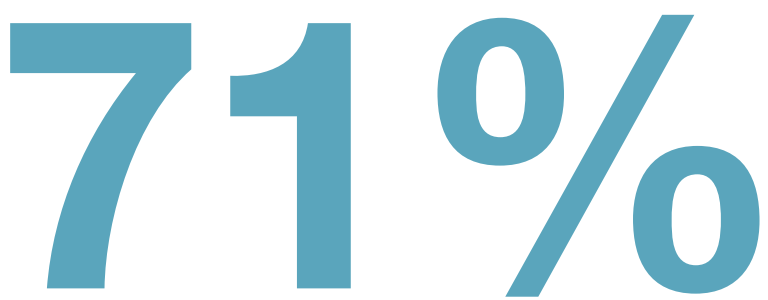


\section{Influence of Water on Business Strategy}

Water management should extend beyond technical intervention that impacts water at a specific facility and instead be embedded within the organization's strategy. An organization's water management should include governance structure, accountability, water performance standards, supply chain and policy, and will also go beyond an organization's own water use and look to engage stakeholders such as the local community and policy makers.

TAV is the only respondent that aligns their public policy positions with water stewardship goals. They state that as a demonstration of their commitment to water they have been in active collaboration on relevant platforms, such as the Working Group on Water at SKD (the Turkish chapter of WBCSD), the Green Airport program of the CivilAviation Authority in Turkey and CDP Water Program. Coca Cola Içecek and Aksa Akrilik are both reporting that they have publicly demonstrated their commitment to water through sharing their water commitments and disclosing water usage at their plants.

CDP aims to understand the company-wide targets and initiatives set for the respondents for the reporting year. CDP asks to detail both the quantitative and qualitative targets and goals your organization sets and communicates on via your sustainability or other corporate reports.
Higher levels of board oversight for water issues

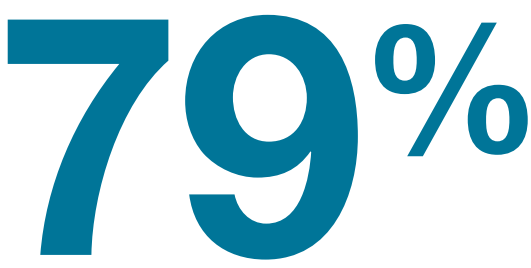

Respondents with targets and goals in place

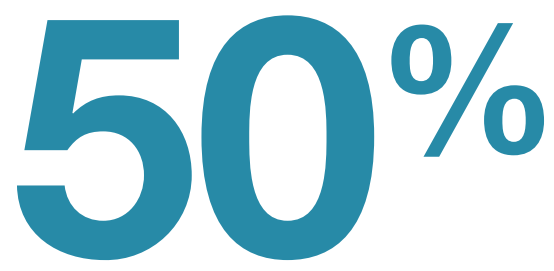

Respondents reporting targets with quantitative actions to manage water resources

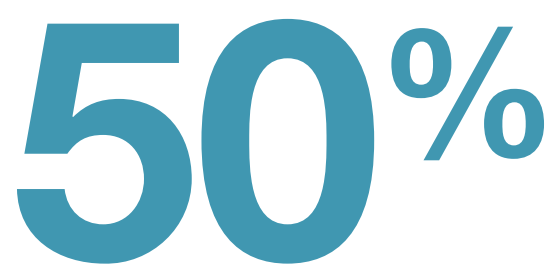

Respondents reporting qualitative goals leading towards improved water stewardship

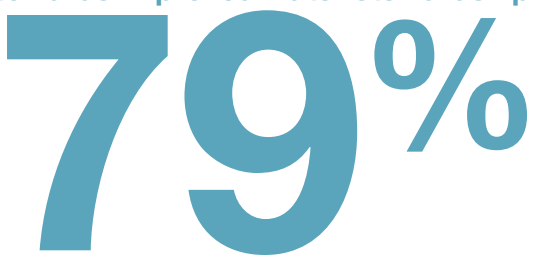

Respondents whose water CAPEX and OPEX increased year on year in the last reporting period

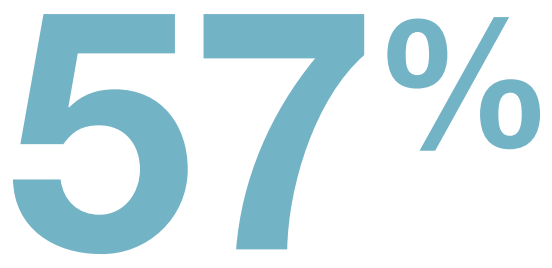

Respondents that have identified any linkages or trade-offs between water and other evironmental impacts
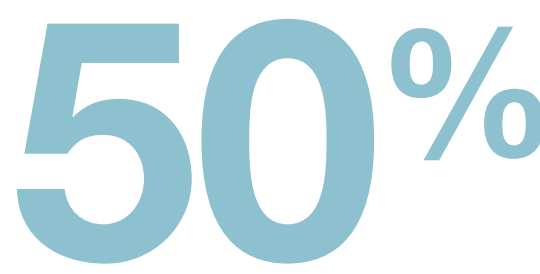
Garanti Bank provides fully functioning WASH services for all employees and a full time OHS team and Construction Department to supervise the quality of these services.

To support Turkey's fight against climate change and to provide solutions to risks like drought, Garanti Bank offered "Agricultural Irrigation Systems Loan" in the first quarter of 2015.

Sekerbank has an ongoing program where we are visiting villages located in rural areas. We have so far visited 10,500 villages and contacted more than 295,000 farmers since 2009. We are planning to visit 10,000 villages and 500.000 farmers in the next 5 years. We are planning to give information about climate change, water problem and mitigations/adaptation methods to farmers in these visits in order to increase awareness in these fields.

Coca Cola İçecek is in the process of Updating Source Vulnerability Analysis (SVA) Study for our plants. 2014 plan was to conduct SVA analysis in Çorlu and İzmir plants.

- Aksa Akrilik is installing an integrated wastewater treatment plant which receives wastewaters from AKSA and other group companies.

- Brisa is enlarging and modernizing staff dressing rooms \& bathrooms to provide better hygiene and wellbeing conditions.
By 2020, Akçansa aims 5\% reduction of water use ratio. The monitoring procedure and system has been improved according to the CSI Water Reporting Guideline

Coca Cola İçecek aims a reduction of water use ratio in all manufacturing plants by 2020. Target is to achieve 1.2 liter use per liter product. In 2014 our water usage ratio is 1,41 $L / L$. And in our base year 2006 , our water usage ratio is 1,74 LL.

Coca Cola İçecek also have a target to safely return $100 \%$ of waste water to nature in 2014 (100\% compliance to legal waste water discharge limits after treatment).

\section{Key indicators: Comparison between CDP Global and Turkey results}

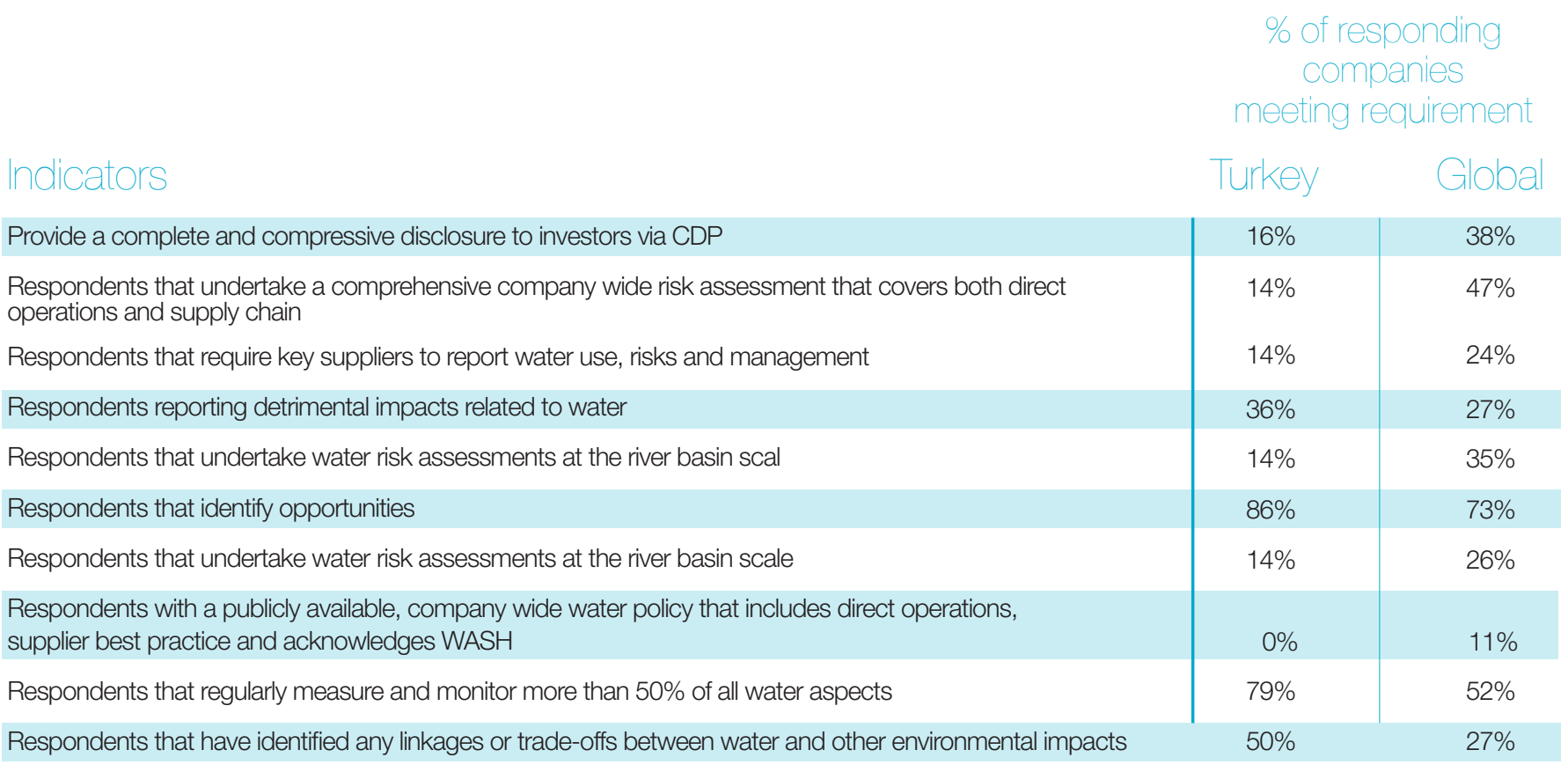




\section{Response Status Table}

\begin{tabular}{|c|c|c|c|c|c|c|c|c|}
\hline $\begin{array}{l}\text { Company } \\
\text { (CDP Turkey Water Sample) }\end{array}$ & 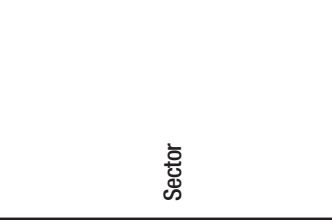 & 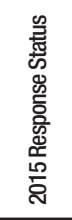 & 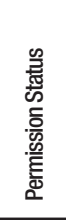 & 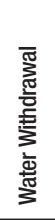 & 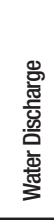 & 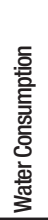 & 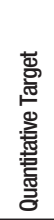 & 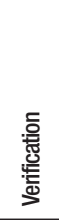 \\
\hline AFYON ÇIMENTO SANAYI T.A.Ş. & Materials & NR & & & & & & \\
\hline AKENERJi ELEKTRIK ÜRETIM A.Ş. & Utilities & $A Q$ & $P$ & D & $\mathrm{D}$ & $\mathrm{D}$ & & \\
\hline AKSA AKRILIK KIMYA SANAYIi A.Ş. & $\begin{array}{l}\text { Consumer } \\
\text { Discretionary }\end{array}$ & $A Q$ & $P$ & D & $\mathrm{D}$ & D & & \\
\hline AKSA ENERJi ÜRETIM A.Ş. & Utilities & NR & & & & & & \\
\hline ALKIM ALKALI KIMYA A.S & Materials & NR & & & & & & \\
\hline ANADOLU CAM SANAYII A.Ş. & Materials & NR & & & & & & \\
\hline ANADOLU EFES BIRACILIK VE MALT SANAYIi A.Ş. & Consumer Staples & NR & & & & & & \\
\hline ARÇELIK A.Ş. & Consumer Discretionary & $\mathrm{DP}$ & & & & & & \\
\hline ASELSAN ELEKTRONIK SANAYI VE TICARET A.Ş. & Industrials & $\mathrm{DP}$ & & & & & & \\
\hline AYGAZ A.Ş. & Utilities & NR & & & & & & \\
\hline BAGFAŞ BANDIRMA GÜBRE FABRIKALARI A.Ş. & Materials & NR & & & & & & \\
\hline BIM BIRLEŞiK MAĞAZALAR A.Ş. & Consumer Staples & DP & & & & & & \\
\hline BiZIM TOPTAN SATIŞ MAĞAZALARI A.Ş. & Consumer Staples & NR & & & & & & \\
\hline BORUSAN MANNESMANN BORU SANAYI VE TICARET A.Ş. & Materials & NR & & & & & & \\
\hline BRISA BRIDGESTONE SABANCI LASTIK SAN. VE TiC. A.Ş & Consumer Discretionary & $A Q$ & $P$ & D & $\mathrm{D}$ & $\mathrm{D}$ & $\mathrm{D}$ & D \\
\hline ÇIMSA ÇIMENTO SANAYIi VE TICARET A.Ş. & Materials & $A Q$ & NP & D & D & & & \\
\hline COCA-COLA IÇECEK A.Ş. & Consumer Staples & $A Q$ & $\mathrm{P}$ & D & $\mathrm{D}$ & $\mathrm{D}$ & $\mathrm{D}$ & D \\
\hline $\begin{array}{l}\text { EIS ECZACIBAŞI ILAÇ, SINAi VE FINANSAL YATIRIMLAR SANAYI } \\
\text { VE TICARET A.Ş. }\end{array}$ & Health Care & NR & & & & & & \\
\hline ENKA INŞAAT VE SANAYI A.Ş. & Industrials & NR & & & & & & \\
\hline EREĞLi DEMIR VE ÇELIK FABRIKALARI T.A.Ş. & Materials & DP & & & & & & \\
\hline FORD OTOMOTIV SANAYI A.Ş. & Consumer Discretionary & NR & & & & & & \\
\hline GÖLTAŞ GÖLLER BÖLGESi çiMENTO SAN. VE TiC.A.Ş. & Materials & NR & & & & & & \\
\hline GÜBRE FABRIKALARI T.A.Ş. & Materials & NR & & & & & & \\
\hline IPEK DOĞAL ENERJI KAYNAKLARI ARAŞTIRMA VE ÜRETIM A.Ş. & Energy & NR & & & & & & \\
\hline IZMIR DEMIR ÇELIK SANAYI A.Ş. & Materials & NR & & & & & & \\
\hline KARDEMIR KARABÜK DEMIR ÇELIK SANAYI VE TICARET A.Ş. & Materials & DP & & & & & & \\
\hline KARTONSAN KARTON SANAYI VE TICARET A.Ş. & Materials & $\mathrm{DP}$ & & & & & & \\
\hline KOÇ HOLDING A.Ş. & Industrials & NR & & & & & & \\
\hline KONYA ÇIMENTO SANAYIi A.Ş. & Materials & NR & & & & & & \\
\hline KOZA ALTIN işLETMELERI A.Ş. & Materials & NR & & & & & & \\
\hline KOZA ANADOLU METAL MADENCILIK IŞLETMELERI A.Ş. & Materials & NR & & & & & & \\
\hline MENDERES TEKSTIL SANAYI VE TICARET A.Ş. & $\begin{array}{l}\text { Consumer } \\
\text { Discretionary }\end{array}$ & DP & & & & & & \\
\hline METRO TICARI VE MALI YATIRIMLAR HOLDING A.Ş. & $\begin{array}{l}\text { Consumer } \\
\text { Staples }\end{array}$ & NR & & & & & & \\
\hline MIGROS TICARET A.Ş. & $\begin{array}{l}\text { Consumer } \\
\text { Staples }\end{array}$ & DP & & & & & & \\
\hline OMV PETROL OFISI A.Ş. & Energy & NR & & & & & & \\
\hline PARK ELEKTRIK ÜRETIM MADENCILIK SANAYI VE TICARET A.Ş. & Materials & NR & & & & & & \\
\hline PETKIM PETROKIMYA HOLDING A.Ş. & Materials & $\mathrm{DP}$ & & & & & & \\
\hline SASA POLYESTER SANAYI A.Ş. & Materials & NR & & & & & & \\
\hline
\end{tabular}




\begin{tabular}{|c|c|c|c|c|c|c|c|c|}
\hline $\begin{array}{l}\text { Company } \\
\text { (CDP Turkey Water Sample) }\end{array}$ & $\begin{array}{l}\text { 总 } \\
\stackrel{\infty}{\infty}\end{array}$ & 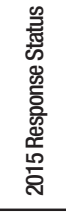 & 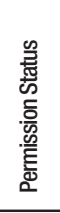 & 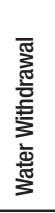 & 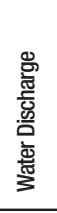 & 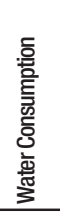 & 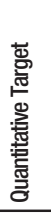 & 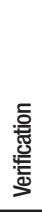 \\
\hline SODA SANAYI A.Ş. & Materials & NR & & & & & & \\
\hline T.ŞiŞE VE CAM FABRIKALARI A.Ş. & Industrials & DP & & & & & & \\
\hline TAT GIDA SANAYii A.Ş. & $\begin{array}{l}\text { Consumer } \\
\text { Staples }\end{array}$ & $\mathrm{DP}$ & & & & & & \\
\hline TAV HAVA LiMANLARI HOLDING A.Ş.(Env list) & Industrials & $A Q$ & $P$ & D & D & & D & \\
\hline TESCO KIPA (Tesco) & $\begin{array}{l}\text { Consumer } \\
\text { Staples }\end{array}$ & SA & & & & & & \\
\hline TOFAŞ TÜRK OTOMOBIL FABRIKASI A.Ş. & $\begin{array}{l}\text { Consumer } \\
\text { Discretionary }\end{array}$ & $A Q$ & $P$ & $\mathrm{D}$ & D & D & D & \\
\hline TRAKYA CAM SANAYIi A.Ş. & Industrials & NR & & & & & & \\
\hline TÜPRAŞ-TÜRKIYE PETROL RAFINERILERI A.Ş. & Energy & NR & & & & & & \\
\hline TURCAS PETROL A.Ş. & Energy & NR & & & & & & \\
\hline TÜRK TRAKTÖR VE ZIRAAT MAKINELERI A.Ş. & Industrials & NR & & & & & & \\
\hline ÜLKER BISKÜVI SANAYI A.Ş. & $\begin{array}{l}\text { Consumer } \\
\text { Staples }\end{array}$ & NR & & & & & & \\
\hline YAZICILAR HOLDING A.Ş. & Industrials & NR & & & & & & \\
\hline ZORLU ENERJI ELEKTRIK ÜRETIM A.Ş. & Utilities & NR & & & & & & \\
\hline $\begin{array}{l}\text { Company } \\
\text { (Other Responding Companies) }\end{array}$ & 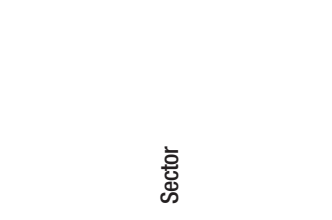 & 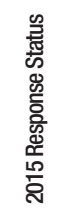 & 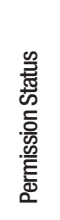 & 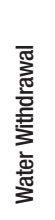 & 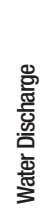 & 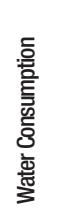 & 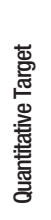 & 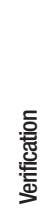 \\
\hline AKÇANSA ÇIMENTO SANAYI VE TICARET A.Ş. & Materials & $A Q$ & $\mathrm{P}$ & $\mathrm{D}$ & D & D & D & \\
\hline IHLAS EV ALETLERI IMALAT SANAYI VE TICARET A.Ş. & Consumer Discretionary & $\mathrm{AQ}$ & NP & & & & & \\
\hline İHLAS HOLDING A.Ş. & Industrials & $A Q$ & $\mathrm{P}$ & & & & & \\
\hline PINAR SÜT MAMULLERI SANAYIi A.Ş. & Consumer Staples & $A Q$ & NP & D & D & D & D & D \\
\hline ŞEKERBANK T.A.Ş. & Financials & $A Q$ & $P$ & $\mathrm{D}$ & $\mathrm{D}$ & D & $\mathrm{D}$ & \\
\hline T.GARANTI BANKASI A.Ş. & Financials & $A Q$ & $P$ & $\mathrm{D}$ & D & D & & \\
\hline YÜNSA YÜNLÜ SANAYI VE TICARET A.Ş. & $\begin{array}{c}\text { Consumer } \\
\text { Discretionary }\end{array}$ & $\mathrm{AQ}$ & NP & $D$ & $\mathrm{D}$ & D & & \\
\hline
\end{tabular}

\section{KEY TO RESPONSE STATUS TABLE}

AQ: Answered Questionnaire

NR: No Response

DP: Declined to Participate

SA: Company is either subsidiary or has merged during the reporting process. See Company brackets for further information on company status.

NP: Non-Public

P: Public

D: Disclosed 
Notes 


\section{Commentary}

\section{Deloitte Turkey}

Deloitte Turkey is delighted to be the 2015 scoring and report writing partner of CDP Turkey.

The Deloitte is committed to driving societal change and promoting environmental sustainability. Working in innovative ways with non-profit organizations, and civil society, we are designing and delivering solutions that contribute to a sustainable and prosperous future for all.

This year is the first year of CDP Water program in Turkey and 15 companies responded. We applaud these companies in addressing one of our most important resource challenges, water scarcity. We believe that businesses that view water resources efficiency as a part of doing business have realized the value that it brings to their corporate objectives related risk management and corporate social responsibility. However, many companies still postpone to prioritize which sustainability initiatives to pursue including resource scarcity, evolving consumer and stakeholder expectations, regulatory changes, and increasing supply chain and operational risks. Addressing these trends through clearly identified risks and opportunities can add incredible value to companies.

Going forward, effectively competing in business means thinking about a new world in terms of resource constraints and stakeholder expectations and innovative ways of addressing them.

\section{Deloitte.}




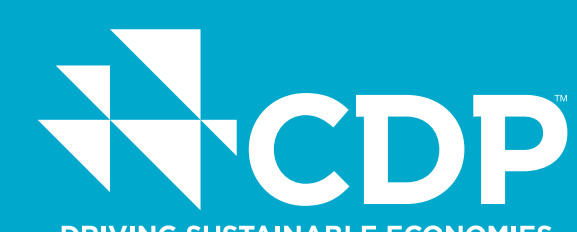

DRIVING SUSTAINABLE ECONOMIES

CDP Partner in Turkey

Sabanci CORPORATE

Univancitesi GOVERAANCE FORUM
OF TURKEY FOR

CDP Water Program Sponsor

\section{\&Garanti}

\section{Report Writers}

Neslihan Beyhan (Deloitte Turkey)

Mirhan Köroğlu Göğüș (CDP Turkey)

CDP Turkey Contacts

Melsa Ararat (Director)

Mirhan Köroğlu Göğüș (Projects Manager)

wWw.cdp.net

http://cdpturkey.sabanciuniv.edu 